\title{
Procoagulant activity of bronchoalveolar lavage fluids taken from the site of tuberculous lesions
}

\author{
P. Selvaraj, N. Venkataprasad, V.K. Vijayan, R. Prabhakar, P.R. Narayanan
}

\begin{abstract}
Procoagulant activity of bronchoalveolar lavage fluids taken from the site of tuberculous lesions. P. Selvaraj, N. Venkataprasad, V.K. Vijayan, R. Prabhakar, P.R. Narayanan. CERS Journals Ltd 1994.

ABSTRACT: We wanted to determine the procoagulant activity (PCA) of bronchoalveolar lavage fluids, in order to understand the macrophage-mediated lung injury at the site of tuberculous lesion.

Alveolar lavage fluids taken from the site of a lesion (radiologically abnormal site (RAS)) and an unaffected site (radiologically normal site (RNS)) of active pulmonary tuberculosis (TB) patients $(n=7)$ and inactive (cured) patients $(n=9)$ were studied for their PCA producing potential. The observed results were not significant using Mann-Whitney test, and thus all increases/decreases reported below are trends/ tendancies only.

An increased PCA was seen in 4 out of 7 cell-free lavage supernatants of activeTB taken from the site of lesion (RAS), compared to only 1 out of 9 in inactiveTB. The PCA producing potential of the alveolar macrophages of RAS and RNS of active-TB patients was enhanced when the alveolar macrophages were cocultured with autologous peripheral blood lymphocytes under in vitro condition. Stimulation with purified protein derivative (PPD) of $M$. tuberculosis showed a variable (increased or decreased) PCA production. Peripheral blood monocytes and total mononuclear cells (monocytes + lymphocytes) of active-TB patients stimulated with or without PPD showed increased PCA production, compared with normal individuals and inactive-TB patients.

The present study suggests that increased production of PCA by the alveolar macrophages, in collaboration with lymphocytes and other cells at the site of tuberculous lesions will result in fibrin formation. The deposition of fibrin in the alveoli may lead to further lung injury.

Eur Respir J., 1994, 7, 1227-1232.
\end{abstract} Tuberculosis Research Centre, Indian Coun-
cil of Medical Research, Madras, India.

Correspondence: P.R. Narayanan Tuberculosis Research Centre (ICMR) Madras 600031

India

Keywords: Alveolar lavage fluids alveolar macrophages

blood monocytes

procoagulant activity

tuberculous lesions

Received: January 271993

Accepted after revision January 271994
Lung parenchymal injury is one of the basic mechanisms involved in the pathogenesis of granulomatous lung diseases. The mechanism of macrophage-mediated tissue injury in the pathogenesis of the granulomatous lung diseases has been extensively reviewed [1]. A complex relationship has been observed between the macrophage and the coagulation-fibrinolytic pathways. Activation of the coagulation system and fibrin deposition has been associated with delayed type hypersensitivity and granulomatous inflammatory reactions. [1, 2]. Fibrin deposition in the alveolar space and in the interstitial tissue is a conspicuous feature of many types of inflammatory reactions [3-5]. Pathways of inflammation and coagulation are closely interrelated at the humoral and cellular levels [6]. Mononuclear phagocytes of various types have been found to display procoagulant activities (PCA), of which thromboplastin (tissue factor) has been shown to be one of the factors which is involved in the formation of fibrin [7]. Other inflammatory cells, such as neutrophils and lymphocytes, do not express PCA [8-11]. However, tissue factor has also been detected in human fibroblasts [12], smooth muscle cells [13], and endothelial cells [14] under in vitro conditions. It has been shown that a variety of stimuli induce the synthesis of PCA in monocytes and macrophages $[8,10,11$, 15].

Pulmonary tuberculosis is a granulomatous disease of the lung caused by $M$. tuberculosis. Altered levels of alveolar macrophages and other inflammatory cells, such as lymphocytes, have been found in the bronchoalveolar lavage (BAL) fluids of tuberculosis patients [16-18].

The present study was carried out to understand the immunopathological changes occurring at the site of tuberculous lesions. PCA production by the activated macrophage has been recognized to be an in vitro measure of cell-mediated immunity. The production of PCA as a tissue factor by monocytes and macrophages, and the release of this factor as a consequence of macrophage and lymphocyte interactions that are involved in the pathogenesis of pulmonary tuberculosis has been studied. 


\section{Materials and methods}

\section{Subjects}

Fibreoptic bronchoscopy and BAL were performed on 7 active pulmonary tuberculosis patients ( 6 nonsmokers and 1 smoker), and 9 inactive pulmonary tuberculosis patients (6 nonsmokers and 3 smokers).

Active tuberculosis patients (ATB). Patients attending the Tuberculosis Research Centre, Madras, with respiratory symptoms and radiographic abnormalities suggestive of pulmonary tuberculosis were evaluated for the study. At the time of initial assessment, all patients had six sputum smears negative for acid-fast bacilli (AFB). These patients had respiratory symptoms of less than 6 months duration and all had minimal radiographic abnormalities in one of the upper zones. None had received any antituberculosis treatment in the past. Among these patients, there were 7 patients whose sputa or lavage fluids had shown growth of Mycobacterium tuberculosis and they were classified as active pulmonary tuberculosis patients.

Inactive tuberculosis (cured) patients (ITB). Patients classified as suffering from active pulmonary tuberculosis (by BAL technique) were given antituberculosis treatment at our centre. All these patients $(n=9)$ had received a short course chemotherapy of 6-8 months duration. BAL was repeated in these patients after chemotherapy. These patients had sputum smears negative for AFB at the time of evaluation. Sputa and lavage cultures were also negative for M. tuberculosis.

\section{Fibreoptic bronchoscopy and bronchoalveolar lavage}

All subjects in the present study were subjected to fibreoptic bronchoscopy and BAL. The procedure for fibreoptic bronchoscopy and BAL has been described previously $[19,20]$, and was performed at the site of lesion of the affected lobe (radiologically abnormal site (RAS)) and at an unaffected site (radiologically normal site (RNS)) from the unaffected lobe. The alveolar lavage fluids of the active and inactive pulmonary tuberculosis (cured) patients were centrifuged at $300 \times \mathrm{g}$ for $10 \mathrm{~min}$. The cell-free supernatants and the alveolar cells were used separately for PCA assay.

\section{Peripheral blood mononuclear cells}

Peripheral blood samples drawn from the active and inactive pulmonary tuberculosis patients who underwent BAL and from normal laboratory volunteers were used. Mononuclear cells were separated using FicollHypaque, as described by Boyum [21]. The cells were washed three times in RPMI-1640 tissue culture medium, with $2 \mathrm{mM}$ L-glutamine (Flow Laboratories, Irvine,
Scotland, UK) containing $10 \%$ foetal bovine serum (FBS) (Intergen Purchase, NY, USA) and gentamicin $50 \mu \mathrm{g} \cdot \mathrm{ml}^{-1}$ (M.A. Bioproducts, Walkersville, Maryland, USA) and fungizone $2.5 \mu \mathrm{g} \cdot \mathrm{ml}^{-1}$ (Squibb, Princefon, NJ, USA). The cells were adjusted to $5 \times 10^{6}$ cells $\cdot \mathrm{ml}^{-1} \mathrm{cul}-$ ture medium.

\section{Differential count}

Smears of alveolar cells from the patients were stained with Diff-Quick (Halerco, Gibbstown, NJ, USA). A total of 300 cells was counted for each smear [17].

\section{Nonspecific esterase staining}

Smears of peripheral blood mononuclear cells were stained for nonspecific esterase for determination of the percentage of monocytes, according to the method of Horwitz et al. [22]. A total of 300 cells was counted, and the percentage monocytes (esterase positive cells) among them was determined.

\section{Design of the experiment}

Five hundred microlitres of $1 \times 10^{6}$ cells $\cdot \mathrm{ml}^{-1}$ concentration of alveolar macrophages, or $5 \times 10^{6}$ cells $\cdot \mathrm{ml}^{-1}$ blood mononuclear cells were seeded in 24-well plates (Costar, Cambridge, MA, USA). The nonadherent cell population, mainly lymphocytes, was removed from the wells seeded with blood mononuclear cells by aspiration after one hour incubation at $37^{\circ} \mathrm{C}$. Alveolar macrophages were used as such. The adherent mononuclear cells (monocytes - nonspecific esterase positive cells) and the alveolar macrophages were cultured for $72 \mathrm{~h}$ at $37^{\circ} \mathrm{C}$, either with or without purified protein derivative (PPD) of M. tuberculosis (Central Veterinary Laboratory, Weybridge, Surrey, UK). In the second set of experiments $1 \times 10^{6}$ cells $\cdot \mathrm{ml}^{-1}$ alveolar macrophages were co-cultured with $4 \times 10^{6}$ cells $\cdot \mathrm{ml}^{-1}$ autologous lymphocytes (1:4 ratio) [23]. In the third set of experiments, $1 \times 10^{6}$ cells $\cdot \mathrm{ml}^{-1}$ alveolar macrophages and $4 \times 10^{6}$ cells $\cdot \mathrm{ml}^{-1}$ autologous lymphocytes were cocultured with $20 \mu \mathrm{g} \cdot \mathrm{ml}^{-1}$ of PPD. In a similar way, $5 \times 10^{6}$ cells $\cdot \mathrm{ml}^{-1}$ peripheral blood mononuclear cells were cultured with or without PPD $\left(20 \mu \mathrm{g} \cdot \mathrm{ml}^{-1}\right)$ for $72 \mathrm{~h}$. The culture supernatants of all the cultures, were taken after $72 \mathrm{~h}$ of incubation at $37^{\circ} \mathrm{C}$ and centrifuged at $400 \times \mathrm{g}$ for $10 \mathrm{~min}$, and the cell-free supernatants were assayed for procoagulant activity.

\section{Assay for procoagulant activity (PCA)}

The procoagulant activity of the cell-free supernatants of the lavage fluids and the spontaneous and PPDstimulated culture supernatants of alveolar macrophages, monocytes, alveolar macrophages co-cultured with autologous lymphocytes, and peripheral blood mononuclear 
cells were measured. The PCA of the supernatants were assessed using a standard one-stage clotting assay [24, 25]. Briefly, $100 \mu \mathrm{l}$ of the supernatants were prewarmed at $37^{\circ} \mathrm{C}$ for $3 \mathrm{~min}$, together with $100 \mu \mathrm{l}$ of $0.025 \mathrm{M}$ calcium chloride, in $76 \times 9 \mathrm{~mm}$ glass tubes. Citrated normal human plasma, $100 \mu \mathrm{l}$, prewarmed to $37^{\circ} \mathrm{C}$, was then added and the clotting time determined by the manual tilt method. All supernatants were assayed in duplicate. A value for the PCA was derived by comparison of the clotting times with the coagulant activity of standard rabbit thromboplastin (Sigma Chemical Co., St. Louis, MO, USA). One hundred microlitres of standard was assigned a value of 1,000 milliunits (mU) of PCA $(10,000$ $\left.\mathrm{mU} \cdot \mathrm{ml}^{-1}\right)$. The activity of the standard was also assayed in duplicates and found to be linear on a $\log / \log$ plot of clotting time against units of PCA, over the range $0.1-1,000$ $\mathrm{mU}$. The PCA of the supernatants were expressed as $\mathrm{mU} \cdot \mathrm{ml}^{-1}$ for cell-free supernatants of the BAL fluids. For in vitro culture supernatants of alveolar macrophages, monocytes and mononuclear cells the PCA is expressed as $\mathrm{mU} \cdot 10^{-5}$ cells.

\section{Statistical methods}

The results are expressed as arithmetic mean \pm standard error (SEM). Statistical analysis was performed using Mann-Whitney U-test (nonparametric test).

\section{Results}

All increases/decreases reported below were found to be not significant using the Mann-Whitney test, and thus indicate trends or tendancies only. The percentage fluid recovery, the total and differential cell count analysis of the alveolar lavage fluids taken from the site of the pulmonary lesion (RAS) and an unaffected site (RNS) of active and inactive (cured) pulmonary tuberculosis patients revealed no difference at the fluid recovery and the cellular level (table 1). Five of the 7 active, and 5 of the 9 inactive TB patients had no lymphocytic alveolitis ( $<20 \%$ lymphocytes).

The cell-free supernatants of the active TB BAL fluids taken from the site of lesion (RAS) showed an increase in the procoagulant activity (mean \pm SEM 130.2 $\pm 52.3 \mathrm{mU}$ ) when compared to the lavage fluids taken from RAS of inactive-TB patients $(24.8 \pm 19.7 \mathrm{mU})$.

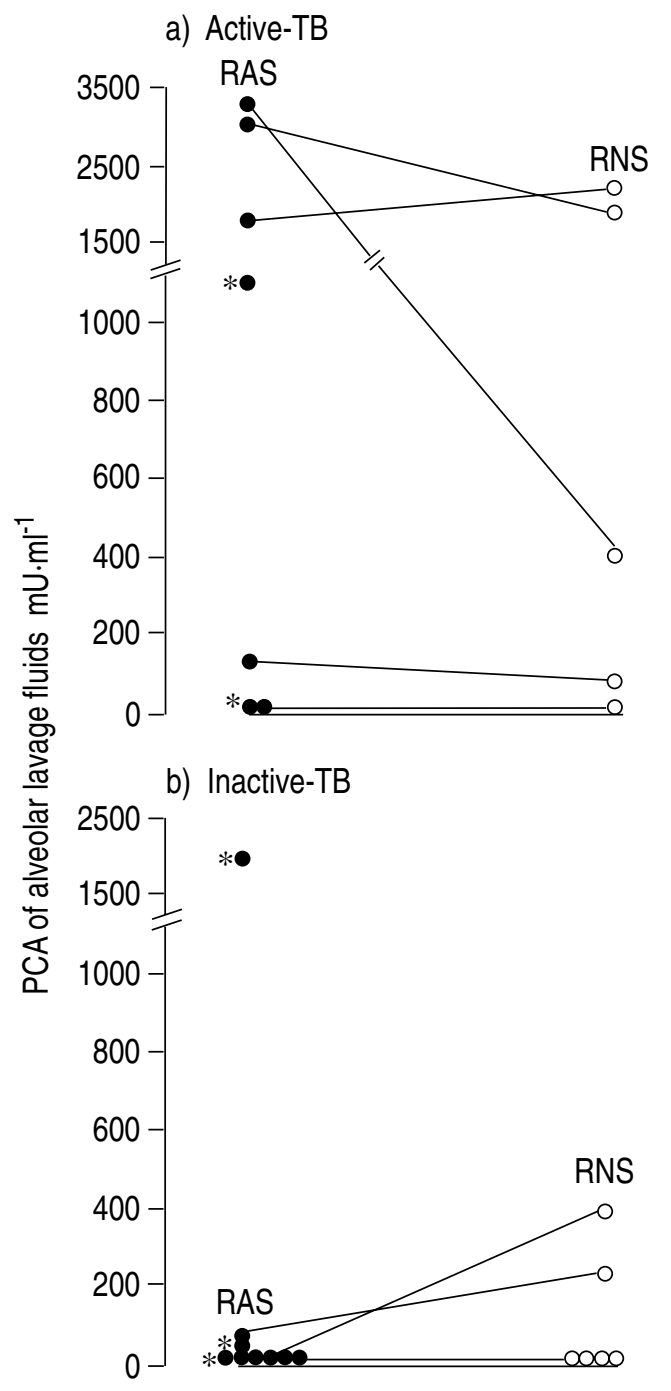

Fig. 1. - Procoagulant activity (PCA) of cell-free supernatants of bronchoalveolar lavage fluids taken from the site of lesion (radiologically abnormal site (RAS)) and an unaffected site other than the infected lobe (radiologically normal site (RNS)) in a) patients with active and $\mathrm{b}$ ) inactive pulmonary tuberculosis, respectively. *: only one sample (RAS) available; corresponding (RNS) sample not determined. •: RAS; o: RNS.

Fig. 1 shows that $3 / 7$ of the active TB group had PCA values $<200 \mathrm{mU} \cdot \mathrm{ml}^{-1}$, similar to the inactive TB group. No difference was observed in the PCA level between RAS (130.2 $\pm 52.3 \mathrm{mU})$ and RNS $(86.1 \pm 44.1 \mathrm{mU})$ of active and inactive tuberculosis patients (fig. 1).

Table 1. - Percentage fluid recovery, total and differential cell counts of alveolar lavage fluids taken from the site of tuberculous pulmonary lesion and an unaffected site

\begin{tabular}{|c|c|c|c|c|c|c|c|c|c|c|c|c|}
\hline \multirow[t]{3}{*}{ Group } & \multicolumn{6}{|c|}{ Site of lesion (RAS) } & \multicolumn{6}{|c|}{ Unaffected site (RNS) } \\
\hline & \multirow{2}{*}{$\begin{array}{l}\% \text { Fluid } \\
\text { recovery }\end{array}$} & \multirow{2}{*}{$\begin{array}{c}\text { Total }^{+} \\
\text {cells }\end{array}$} & \multicolumn{4}{|c|}{ Differential counts \% } & \multirow{2}{*}{$\begin{array}{l}\% \text { Fluid } \\
\text { recovery }\end{array}$} & \multirow{2}{*}{$\begin{array}{l}\text { Total }^{+} \\
\text {cells }\end{array}$} & \multicolumn{4}{|c|}{ Differential counts \% } \\
\hline & & & Mac & Lymph & Neut & Eos & & & Mac & Lymph & Neut & Eos \\
\hline Active-TB* & $64 \pm 8$ & $22 \pm 3$ & $77 \pm 3$ & $17 \pm 3$ & $4 \pm 1$ & $2 \pm 1$ & $69 \pm 6$ & $15 \pm 4$ & $72 \pm 3$ & $20 \pm 2$ & $5 \pm 1$ & $2 \pm 1$ \\
\hline Inactive- $\mathrm{TB}^{+}$ & $61 \pm 4$ & $21 \pm 5$ & $83 \pm 3$ & $12 \pm 3$ & $3 \pm 1$ & $2 \pm 1$ & $64 \pm 7$ & $19 \pm 5$ & $74 \pm 4$ & $19 \pm 4$ & $5 \pm 1$ & $1 \pm 0$ \\
\hline
\end{tabular}

+: $10^{6}$ cells $\cdot \mathrm{dl}^{-1}$; *: RAS $\mathrm{n}=7$ patients, and RNS $\mathrm{n}=5$ patients; + $:$ RAS $\mathrm{n}=9$ patients, and RNS $\mathrm{n}=6$ patients. Mac: macrophages; Lymph: lymphocytes; Neut: neutrophils; Eos: esoinophils. 
Table 2. - Effect of purified protein derivative (PPD) of M. tuberculosis on the PCA producing potential of alveolar macrophages and peripheral blood adherent (monocytes) and nonadherent (lymphocytes) mononuclear cells

\begin{tabular}{|c|c|c|c|c|c|c|c|}
\hline \multirow[t]{3}{*}{ Subjects } & \multicolumn{4}{|c|}{$\begin{array}{l}\text { Alveolar macrophages } \\
\text { PCA in mU* }\end{array}$} & \multicolumn{3}{|c|}{$\begin{array}{l}\text { Peripheral blood } \\
\text { PCA in mU*t }\end{array}$} \\
\hline & \multicolumn{2}{|c|}{ Site of lesion (RAS) } & \multicolumn{2}{|c|}{ Unaffected site (RNS) } & \multirow{2}{*}{$\begin{array}{c}\text { Adherent } \\
\text { mononuclear } \\
\text { cells }\end{array}$} & \multirow{2}{*}{$\begin{array}{c}\text { Adherent } \\
\text { mononuclear } \\
\text { cells + PPD }\end{array}$} & \multirow{2}{*}{$\begin{array}{c}\text { Non-adherent } \\
\text { mononuclear } \\
\text { cells }\end{array}$} \\
\hline & $\mathrm{AM}$ & $\begin{array}{c}\mathrm{AM} \\
+ \\
\mathrm{PPD}\end{array}$ & $\mathrm{AM}$ & $\begin{array}{c}\mathrm{AM} \\
+ \\
\mathrm{PPD}\end{array}$ & & & \\
\hline Active-TB & $\begin{array}{c}15.8 \pm 6.3 \\
(\mathrm{n}=5)\end{array}$ & $\begin{array}{c}32.1 \pm 22.6 \\
(n=5)\end{array}$ & $\begin{array}{l}21.8 \pm 20.8 \\
(\mathrm{n}=5)\end{array}$ & $\begin{array}{l}32.7 \pm 31.8 \\
\quad(\mathrm{n}=5)\end{array}$ & $\begin{array}{c}15.9 \pm 12.9 \\
(\mathrm{n}=6)\end{array}$ & $\begin{array}{c}12.1 \pm 9.2 \\
(\mathrm{n}=6)\end{array}$ & $\begin{array}{c}8.2 \pm 3.8 \\
(\mathrm{n}=6)\end{array}$ \\
\hline Inactive-TB & $\begin{array}{c}8.9 \pm 7.6 \\
(n=6)\end{array}$ & $\begin{array}{c}14.6 \pm 10.7 \\
(n=6)\end{array}$ & $\begin{array}{c}13.5 \pm 8.0 \\
(n=6)\end{array}$ & $\begin{array}{c}22.5 \pm 14.8 \\
\quad(n=6)\end{array}$ & $\begin{array}{c}0.8 \pm 0.4 \\
(n=8)\end{array}$ & $\begin{array}{c}2.6 \pm 1.1 \\
(n=8)\end{array}$ & $\begin{array}{c}0.9 \pm 0.4 \\
(\mathrm{n}=8)\end{array}$ \\
\hline Normals & ND & ND & ND & ND & $\begin{array}{l}0.22 \pm 0.13 \\
\quad(\mathrm{n}=7)\end{array}$ & $\begin{array}{l}0.4 \pm 0.3 \\
(n=7)\end{array}$ & ND \\
\hline
\end{tabular}

Mean士SEM. Numbers in parentheses represent the actual number of subjects studied. ND: not determined; AM: alveolar macrophages; PCA: procoagulant activity. *: PCA in mU per $10^{5}$ alveolar macrophages (AM) or peripheral blood adherent (monocytes) cells; +: PCA in mU per $5 \times 10^{5}$ peripheral blood nonadherent (lymphocytes) cells. More than $95 \%$ of the nonadherent cell population were lymphocytes.
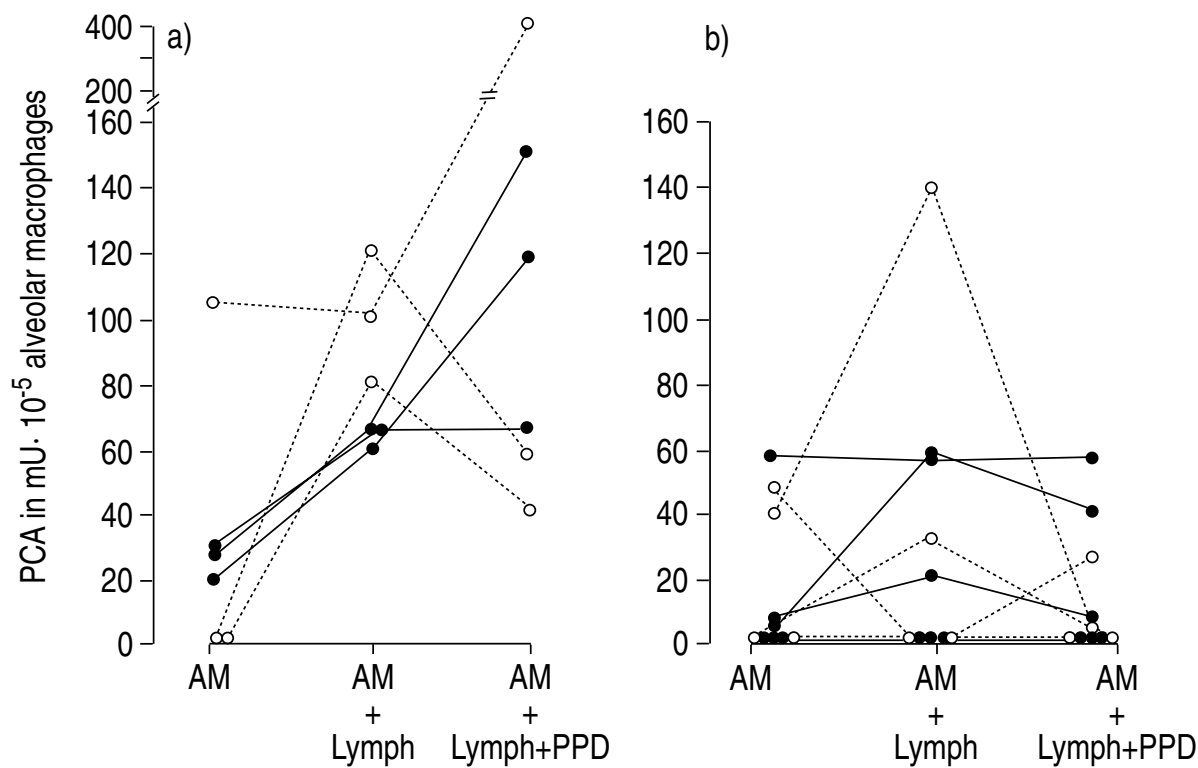

Fig. 2. - Effect of autologous lymphocytes and purified protein derivative (PPD) $\left(20 \mu \mathrm{g} \cdot \mathrm{ml}^{-1}\right)$ on the PCA producing potential of alveolar macrophages (AM). The PCA producing potential of alveolar macrophages taken from the site of lesion (RAS) and unaffected site (RNS) of: a) 3 active; and b) 6 inactive (cured) pulmonary tuberculosis patients were studied independently and compared. For abbreviations see legend to figure 1. $\bullet \bullet:$ RAS; o---o: RNS.

The procoagulant activity releasing potential of the alveolar macrophages harvested from patients with active or inactive tuberculosis was similar. Furthermore, stimulation of alveolar macrophages with PPD showed a moderate increase in the PCA of alveolar macrophages taken from RAS and RNS of active-TB and inactiveTB patients (table 2).

When the alveolar cells from patients with active tuberculosis were co-cultured with autologous lymphocytes (1:4 ratio) an increase in the PCA was evident, compared to the PCA released by the alveolar macrophages alone (fig. 2). An increased PCA response was seen with the macrophages of RNS when compared to RAS recruited macrophages of active-TB patients

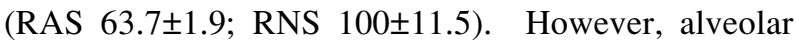
macrophages of RAS and RNS of active-TB patients co-cultured with autologous lymphocytes and PPD showed a variable (enhanced or suppressed) PCA release, compared to non-PPD stimulated cells (fig. 2a). In inactive-TB patients, cultures of alveolar macrophages with autologous lymphocytes, with or without stimulation with PPD showed variable responses (fig. 2b).

The PCA of the peripheral blood monocytes of active$\mathrm{TB}$ or inactive-TB patients was comparable to that of the alveolar macrophages of either active or inactive stage of tuberculosis (figs. 2 and 3).

The spontaneous and PPD-induced procoagulant activity of the peripheral blood adherent mononuclear cells 
a)

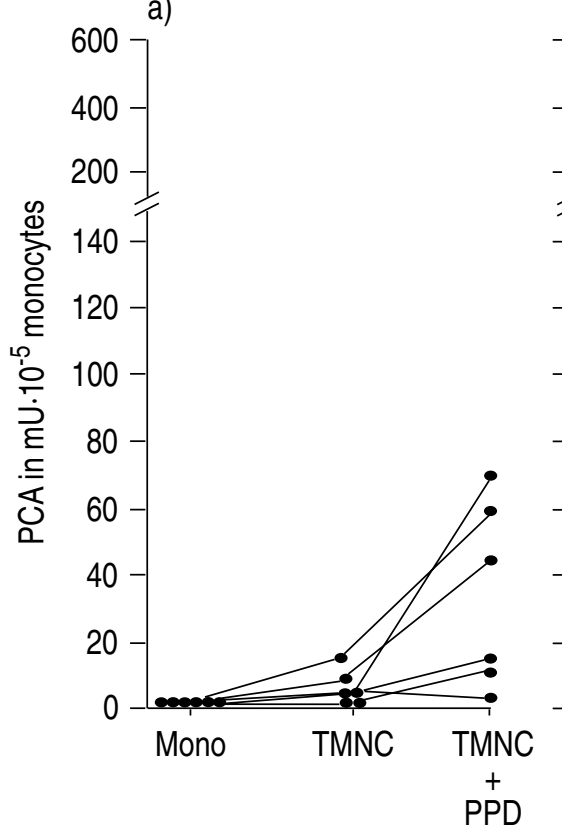

b)



c)

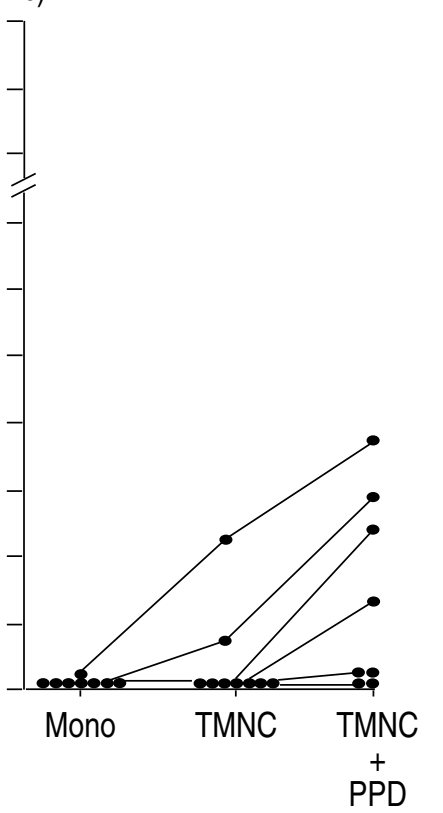

Fig. 3. - The spontaneous and PPD $\left(20 \mu \mathrm{g} \cdot \mathrm{ml}^{-1}\right)$ induced procoagulant activity of peripheral blood monocytes (Mono) and total mononuclear cells (monocytes and lymphocytes) (TMNC) of: a) normal; b) active; and c) inactive (cured) pulmonary tuberculosis patients. PPD: purified protein derivative; PCA: procoagulant activity.

was higher in cells derived from active-TB patients than from the inactive-TB patients and normal individuals (table 2). When the total mononuclear cells of activeTB patients were stimulated with PPD, 5/7 patients showed an increase in their PCA production. This appears similar to the responses in inactive-TB and normals (fig. 3).

\section{Discussion}

Bronchoalveolar lavage fluids and lung alveolar macrophages from humans have been shown to contain procoagulant activities [25-29]. Furthermore, it has been shown that the PCA of the lavage fluids are membrane vesicles consisting exclusively of alveolar macrophage membrane material $[25,29,30]$. In the present study, an increased procoagulant activity was seen in the cell-free supernatants of active-TB lavage fluids taken from the site of lesion (RAS) compared to the lavage fluids from inactive-TB patients. This increase was not significant, however, and thus indicates a trend only. The same is true for the other differences observed in this study.

The increased procoagulant activity of the cell-free supernatants of the lavage fluids may be due to the PCA containing microvesicles that are released at the site of lesion (RAS) by the alveolar macrophages and other cells, such as fibroblasts [12], to promote coagulation.

Alveolar lavage fluids taken from RAS and RNS of active-TB patients showed no difference in their PCA level. This suggests that the alveolar macrophages which are residing at the site of lesion (RAS) and at the unaffected site (RNS) are equally sensitized to the antigens of $M$. tuberculosis, and capable of releasing
PCA into the microenvironment of the alveolar space. In contrast, lavage fluids taken from radiologically abnormal site of inactive-TB patients showed a low level of PCA. This low level of PCA in the BAL fluids of inactive-TB patients may be due to an unresponsive state of the alveolar macrophages, or to a low proportion of M. tuberculosis sensitized macrophages, at the sites of RAS and RNS.

Alveolar macrophages taken from the site of lesion (RAS) and unaffected site (RNS) of both active-TB and inactive-TB patients produced a low level of spontaneous and PPD-induced PCA in vitro. However, alveolar macrophages co-cultured with autologous lymphocytes (1:4 ratio) showed a variable (increased or decreased) spontaneous and PPD-induced PCA production. This reveals that the PCA-releasing potential of alveolar macrophages is influenced by lymphocytes, and that lymphocyte co-operation seems necessary for the increased PCA production. It has been shown that T-lymphocytes [23] and T-lymphocyte factors [31] are important for the increased production of PCA by the monocytes and macrophages. Further, the monocyte procoagulant-inducing factor (MPIF) has been shown to be a T-helper cell derived cytokine, that may play a collaborative role in the expression of cell-mediated immune responses [32].

The PCA releasing potential of the peripheral blood monocytes, monocytes co-cultured with lymphocytes as mononuclear cells with or without stimulation with PPD, was also comparable to that of the alveolar macrophages of the active-TB and inactive-TB patients. Peripheral blood monocytes and mononuclear cells of normal subjects produced a low level of PCA. Mononuclear blood cells with or without stimulation with PPD showed a higher PCA production in active-TB 
patients than in inactive-TB patients and normal subjects. This suggests that the peripheral blood monocytes and the lymphocytes of active tuberculosis patients are sensitized to PPD antigen. The monocytes and lymphocytes of inactive-TB patients and normal subjects are in an unresponsive state or less sensitized to the stimulating antigen.

The present study suggests that the alveolar macrophages taken from the site of lesion (RAS) and the unaffected site (RNS) of the active-TB patients are equally competent in their PCA producing potential. Increased production of procoagulant activity by the alveolar macrophages of active-TB patients during inflammation may result in fibrin formation, a cellmediated immune reaction. The fibrin deposition in the alveolar space and interstitial tissue may lead to further lung injury.

Acknowledgements: The authors sincerely thank A. Joy and K. Sankaran for their help with the BAL procedure and V. Shanthi for typing the manuscript.

\section{References}

1. Hunninghake GW, Garrett KC, Richerson $\mathrm{HB}$, et al. Pathogenesis of the granulomatous lung diseases. Am Rev Respir Dis 1984; 130: 476-496.

2. Fantone JC, Ward PA. Mechanisms of lung parenchymal injury. Am Rev Respir Dis 1984; 130: 484-491.

3. Spencer H. In: Pathology of the Lung. 3rd edn. Philadelphia, USA, Saunders Co., 1977; pp. 235-240.

4. Pratt P. In: The Lung, Structure, Function and Disease. Baltimore, USA, William \& Wilkins Co., 1978; pp. 43-57.

5. Saldeen T. The occurrence of fibrin in the lungs in an autopsy material. Virchows Arch (Pathol Anat) 1967; 343: $20-25$.

6. Zimmerman TS, Fierer J, Rothberger H. Blood coagulation and the inflammatory response. Semin Haematol 1977; 14: 391-408.

7. Prydz H. Triggering of the extrinsic blood coagulation system. In: Thomson JM, ed. Blood Coagulation and Haemostasis. Churchill-Livingstone, 3rd edn, 1985; pp. $1-21$.

8. Rivers RP, Hathaway WE, Weston WL. Endotoxininduced coagulant activity of human monocytes. $\mathrm{BrJ}$ Haematol 1975; 30: 311-316.

9. Edwards RL, Rickles FR, Bolorove AM. Mononuclear cell tissue factor. Cell of origin and requirements for activation. Blood 1979; 54: 359-370.

10. Levy GA, Schwartz BS, Edgington TS. The kinetics and metabolic requirements for direct lymphocyte induction of human procoagulant monokines by bacterial polysaccharide. J Immunol 1981; 127: 357-363.

11. Schwartz BS, Edgington TS. Immune complexinduced human monocyte procoagulant activity. I. A rapid undirectional lymphocyte instructed pathway. $J$ Exp Med 1981; 154: 892-906.

12. Zacharski LR, McIntyre OR. Membrane-mediated synthesis of tissue factor (thromboplastin) in cultured fibroblasts. Blood 1973; 41: 679-685.

13. Maynard JR, Drayer BE, Stemerman MB, Pitlick FA. Tissue factor coagulant activity of cultured human endothelial and smooth muscle cells and fibroblasts. Blood 1977; 50: 387-396.

14. Uchman B, Bang NU, Rathbun MJ, Fineberg NS. Eff- ect of insulin immune complexes on human blood monocyte and endothelial cell procoagulant activity. $J$ Lab Clin Med 1988; 112: 652-659.

15. Schwartz BS. Antigen-induced monocyte procoagulant activity. Requirement for antigen presentation and histocompatibility leukocyte antigen-DR molecules. J Clin Invest 1985; 76: 970-977.

16. Venkataprasad N. Immunological functions of alveolar macrophages in pulmonary tuberculosis. PhD thesis, University of Madras, India, 1990.

17. Selvaraj P, Venkataprasad N, Vijayan VK, Narayanan PR. Altered bactericidal activity against staphylococcus aureus in tuberculous bronchoalveolar lavage fluids. Eur Respir J 1994; 7: 121-126.

18. Ozaki T, Nakahira S, Tani K, Ogushi F, Yasuoka S, Ogura T. Differential cell analysis in bronchoalveolar lavage fluid from pulmonary lesions of patients with tuberculosis. Chest 1992; 102: 54-59.

19. Hunninghake GW, Gadek JE, Kawanami O, Ferrans VJ, Crystal RJ. Inflammatory and immune processes in the human lung in health and disease: evaluation by bronchoalveolar lavage. Am J Pathol 1979; 97: 149-206.

20. Selvaraj P, Rajiswamy S, Vijayan VK, Prabhakar R, Narayanan PR. Hydrogen peroxide producing potential of alveolar macrophages and blood monocytes in pulmonary tuberculosis. Ind J Med Res 1988; 88: 124-129.

21. Boyum A. Separation of leukocytes from blood and bone marrow. Scand J Clin Lab Invest 1968; 21 (Suppl.): 97-102.

22. Horwitz DA, Allison AC, Ward P, Knight N. Identification of human mononuclear leucocyte populations by esterase staining. Clin Exp Immunol 1977; 30: 289-298.

23. Levy GA, Edgington TS. Lymphocyte co-operation is required for amplification of macrophage procoagulant activity. J Exp Med 1980; 151: 1232-1244.

24. Tipping PG, Dowling JP, Holdsworth SR. Glomerular procoagulant activity in human proliferative glomerulonephritis. J Clin Invest 1988; 81: 119-125.

25. Lyberg T, Nakstad B, Hetland O, Boye NP. Procoagulant (thromboplastin) activity in human bronchoalveolar lavage fluids is derived from alveolar macrophages. Eur Respir J 1990; 3: 61-67.

26. Chapman HA, Allen CL, Stone OL, Fair DS. Alveolar macrophages synthesize factor VII in vitro. Possible role in interstitial lung disease. J Clin Invest 1985; 75 : 2030-2037.

27. Idell S, Gonzalez K, Bradford H, et al. Procoagulant activity in bronchoalveolar lavage in the adult respiratory syndrome. Am Rev Respir Dis 1987; 136: 1466-1474.

28. Chapman HA, Stahl M, Allen CL, Yee R, Fair DS. Regulation of the procoagulant activity within the bronchoalveolar compartment of normal human lung. Am Rev Respir Dis 1988; 137: 1417-1425.

29. Nakstad B, Boye NP, Lyberg T. Procoagulant activities in human alveolar macrophages. Eur J Respir Dis 1987; 71: 459-471.

30. McGee MP, Rothberger H. Tissue factor in bronchoalveolar lavage fluids. Evidence for an alveolar macrophage source. Am Rev Respir Dis 1985; 131: 331-336.

31. Sao-Tah Fan, Edgington TS. Clonal analysis of mechanisms of murine T-helper cell collaboration with effector cells of macrophage lineage. J Immunol 1988; 141: 1819-1827.

32. Sao-Tah Fan, Glasebrook AL, Edgington TS. Clonal analysis of CD4+ T-helper cell subsets that induce the monocyte procoagulant response. Cell Immunol 1990; 128: $52-62$. 